\title{
Văn hóa kinh doanh - Hành trang để hội nhập
}

\author{
Duy Xuyên \\ Sài Gòn Giải Phóng \\ November 3, 2007 \\ https://www.sggp.org.vn/van-hoa-kinh-doanh-hanh-trang-de-hoi-nhap- \\ 90666.html
}




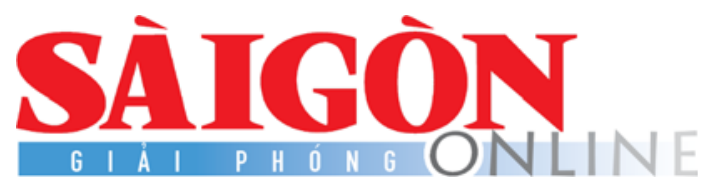

Chính trị Xã hội Pháp luật Kinh tế Thế giới Đời sống công nghệ Giáo dục Khoa học công nghệ

MỤC KHÁC | SÁCH VÀ CUộC SỐNG

"Văn minh làm giàu và nguồn gốc của cải"

\section{Văn hóa kinh doanh - Hành trang để hội nhập}

Thứ Bảy, 3/11/2007 23:19

Có thể nói chưa bao giờ "đạo kinh doanh" được chú ý như trong giai đoạn này, nhất là khi Việt Nam gia nhập WTO. Để có thể hội nhập, hành trang mà những nhà kinh doanh mang theo không chỉ có bản lĩnh mà còn phải có kiến thức, văn hóa kinh doanh. Nắm bắt nhanh nhu cầu của đối tượng này, các NXB đã cho ra mắt hàng loạt các tủ sách kinh doanh trong đó có cuốn "Văn minh làm giàu và nguồn gốc của cải” (tác giả: TS Vương Quân Hoành - NXB Chính trị Quốc gia).

\section{Saca

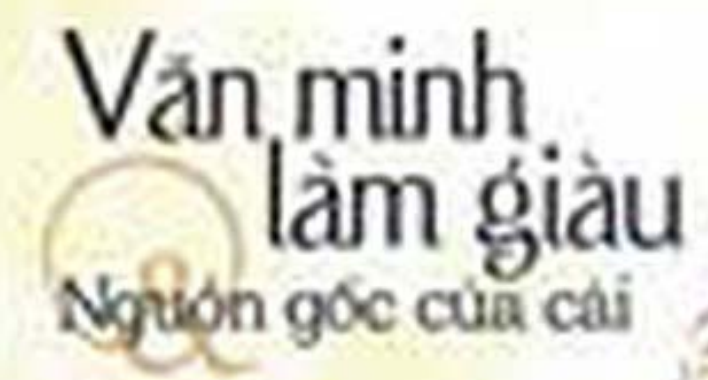




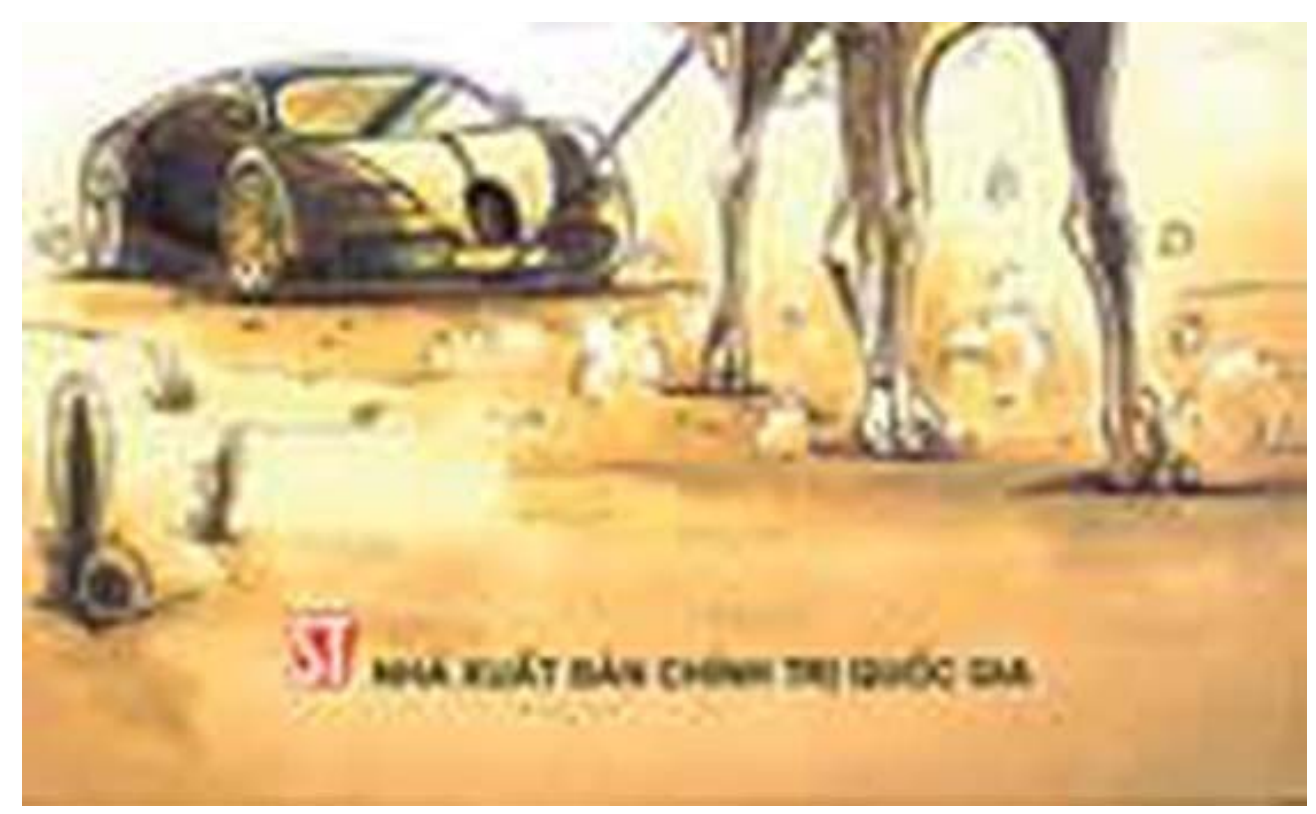

Điều thú vị đầu tiên khi bạn đọc tiếp cận cuốn sách đó là sự hấp dẫn, do lối viết khá mềm mại. Đề cập đến vấn đề kinh tế nhưng TS Vương Quân Hoành lại thể hiện bằng bút pháp giàu hình ảnh minh họa, sinh động nhưng không kém phần logic và thuyết phục về các chủ đề: Văn hóa kinh doanh: Các góc nhìn (Truyền thống văn hóa kinh doanh, Khi các giá trị khác biệt...); Văn hóa kinh doanh: Hệ thống (Ảnh hưởng của Khổng giáo, Niềm tin Giá trị - Tư duy - Hành vi...); Giáo dục trong kinh doanh...

Ở phần "Đặc tính quan hệ cá nhân" trong kinh doanh, có những câu chuyện khiến bạn đọc cười ra nước mắt. Nhiều doanh nghiệp muốn giới thiệu sản phẩm của mình đến người tiêu dùng một cách nhanh nhất nhưng lại chỉ quan tâm đến cái mình cần mà bỏ qua cảm nhận của người thu nhận thông tin. Đó là những cách quảng cáo theo kiểu "Lườm rau gắp thịt" và trở thành "Một thứ quy luật hủy hoại văn hóa kinh doanh của người Việt Nam".

Rất nhiều suy tư của tác giả đã dược đẩy thành vấn đề trong "Văn minh làm giàu và nguồn gốc của cải". Từ những chuyện như: độc quyền sách giáo khoa, cây cà phê Việt Nam... xen lẫn những nỗi buồn là niềm tự hào về kinh doanh của nước ta. Đặc biệt quy luật sinh - lão - bệnh - tử vốn có từ rất lâu được tác giả liên tưởng đến sự trường tồn của các doanh nghiệp Việt: "Ở Việt Nam có thể thấy nhiều cụ già thọ tới trên 100 tuổi, nhưng còn doanh nghiệp "thượng thọ" thì sao? Vì sao không tìm thấy doanh nghiệp Việt Nam 100 tuổi”. Phải chăng văn minh, đạo của những người kinh doanh góp phần làm nên điều kiện cần và đủ cho sự "thượng thọ" ấy?

Xây dựng văn hóa kinh doanh là một vấn đề rất khó khăn bởi nó chưa trở thành hệ thống và phổ biến ở nước ta. Văn hóa là ranh giới phân biệt giữa kinh doanh và kiếm tiền, là nhân tố quan trọng dẫn chúng ta đến văn minh kinh doanh. Không ai chối bỏ việc kinh doanh phải gắn liền với lợi nhuận, thế nhưng hai giáo sư John Kotter và James Heskett tại trường đại học hàng đầu trên thế giới là Harvard đã nghiên cứu về "Văn hóa công ty và chỉ số hoạt động hữu ích" với kết quả đáng chú ý: "Lãi ròng của các công ty "đạo đức cao" ở Mỹ trong 11 năm đã tăng tới 756\%. Trên cơ sở kết quả nghiên cứu này, hai giáo sư đã khẳng định thật thà giàu hơn".

Trong một hệ thống kinh doanh có phương pháp, việc xây dựng các chuẩn mực đạo đức trong cư xử và giao thương chính là nền móng để các hệ thống kinh doanh phát triển bền vững. Đây là một trong những yếu tố thiết yếu mà giới doanh nghiệp nước ta đang hướng tới. Lợi nhuận sẽ tăng theo đạo đức nếu người kinh doanh hiểu được "Văn minh làm giàu và nguồn gốc của cải”.

\section{DUY XUYÊN}




\section{Tài liệu tham khảo:}

Duy Xuyên. (2007). Văn hóa kinh doanh - Hành trang để hội nhập. Sài Gòn Giải Phóng, $3 / 11 / 2007$.

Vương Quân Hoàng. (2007). Văn minh làm giàu \& nguồn gốc của cải. Nxb Chính trị quốc gia, Hà Nội. 